\title{
Possible association between type 2 diabetes mellitus and Hashimoto's autoimmune thyroiditis - final results
}

\author{
Posibila asociere dintre diabetul zaharat de tip 2 şi \\ tiroidita autoimună Hashimoto - rezultate finale
}

\author{
Oana-Andreea Parlițeanu' ${ }^{1}$ Dan-Mircea Cheța ${ }^{2,3}$ \\ ${ }^{1}$ Institutul Național de Pneumoftiziologie „Marius Nasta“, București, România \\ ²Universitatea de Medicină și Farmacie „Carol Davila“, București, România \\ IInstitutul Național de Diabet Zaharat, Nutriție și Boli Metabolice "Prof. Dr. N.C. Paulescu“, \\ București, România
}

\begin{abstract}
Introduction. The idea for our clinical research came from the association between type 2 diabetes and autoimmune thyroiditis that we often see in our daily practice. We wanted to study this to see if it is only a coincidence or if indeed this association really exists.

Method. We created an observational retrospective research using 5,064 patients with type 2 diabetes, patients from Sanamed Hospital, which came at site between January 2016 and December 2018. Out of the large group of patients, we created 3 secondary groups: one containing 50 patients with type 2 diabetes, one with 50 patients with autoimmune thyroiditis and one with 50 patients which had both diseases. We initially evalueted the large group and after that we studied the 3 smaller groups.

Results. We were able to prove the main hypothesis of our study by showing that the incidence of thyroiditis was significantly higher in the population with type 2 diabetes from our main group, the 5,064 patients, in contrast with the incidence that thyroiditis has in the healthy population from Europe. In our study we also demonstrated that the association between this 2 diseases has a protective role in regards with the incidence of obesity, arterial hypertension, dyslipidemia and macrovascular complications of the type 2 diabetes. Also, we found out that in the case of this association there are significant differences for a serial of biochemical parameters as well, such as blood glucose, uric acid, elements of the lipid profile.

Discussions. The results from our study were consistent with the results form other international studies regarding this topic. This finding led us to the conclusion that our initial observation, that this two conditions might be associated, was not only a coincidence, but it is a definite association proved by us in this study. Conclusions. We proved our initial hypothesis to be true by the significant difference in incidence of thyroiditis in the population of our study in comparison with the incidence of thyroiditis in the healthy European population. We also managed to prove the secondary hypothesis to be correct.
\end{abstract}

Keywords: type 2 diabetes, Hashimoto atoimmune thyroiditis, association

\section{REZUMAT}

Introducere. Studiul nostru a plecat de la o asociere pe care am întâlnit-o frecvent în practica noastră curentă și ne-am dorit să vedem dacă ceea ce am sesizat noi este doar o coincidență sau există date clinice și paraclinice care să susțină o posibilă asociere între diabetul zaharat de tip 2 (DZ2) și tiroidita autoimună Hashimoto $(\mathrm{TH})$.

Materiale şi metodă. Am evaluat, într-un studiu observațional restrospectiv, 5.064 pacienți cu diabet zaharat tip 2. Acești pacienți s-au prezentat la clinica Sanamed Hospital în perioada ianuarie 2016-decembrie 2018. Din lotul inițial de pacienți, am selectat 3 loturi: unul format din 50 pacienți cu DZ2, unul format din 50 pacienți cu TH și unul format din 50 pacienți care aveau DZ2 și TH. Am analizat lotul inițial și cele 3 loturi ulterior formate pentru a demonstra asocierea dintre cele două patologii.

Rezultate. Incidența TH în rândul lotului de 5.064 pacienți cu DZ2 a fost semnificativ mai mare decât incidența TH la nivelul populației sănătoase din Europa. Acest rezultat a confirmat ipoteza inițială a studiului: cele două patologii se asociază. Asocierea DZ2 cu TH a avut efecte protectoare pentru obezitate, hipertensiune arterială (HTA), dislipidemie și complicații macrovasculare ale diabetului zaharat. Am mai constatat diferențe semnificativ statistice și în ceea ce privește unii parametri biochimici precum glicemia, acidul uric, elemente ale profilului lipidic. 
Discuţii. Rezultatele din studiul nostru au fost în concordanță cu rezultate ale altor studii internaționale legate de această temă, ceea ce ne-a făcut să concluzionăm faptul că ceea ce am constatat inițial nu este doar o coincidență, ci este o asociere certă demonstată de către noi prin intermediul acestei cercetări.

Concluzii. Am confirmat ipoteza inițială a studiului nostru prin faptul că am demonstrat o incidență mai mare a TH în rândul pacienților cu DZ2 versus incidența TH din rândul populației sănătoase generale de la nivel european. Diferența dintre incidențe a fost puternic semnificativă, ceea ce a demonstrat ipoteza principală a studiului nostru, și anume că DZ2 și TH se asociază. Am mai confirmat și ipotezele secundare ale studiului.

Cuvinte cheie: diabet zaharat tip 2, tiroidită autoimună Hashimoto, asociere

\section{INTRODUCERE}

În practică noastră uzuală, am constatat o rată crescută a incidenței tiroiditei autoimune Hashimoto în rândul populației cu diabet zaharat tip 2, fapt care ne-a atras atenția și ne-a făcut să ne întrebăm dacă nu există oare o posibilă asociere între aceste două patologii. Căutând în literatura de specialitate, am găsit doar date referitoare la asocierea dintre diabetul zaharat tip 1 și tiroidita cronică limfocitară, ambele având mecanism fiziopatologic autoimun. Astfel, ne-am propus ca, printr-un studiu original, să vedem, în primul rând, dacă ceea ce noi am constatat se confirmă (asocierea DZ2 cu $\mathrm{TH})$ și care sunt elementele comune care pot duce la această posibilă asociere.

Am observat tipologia pacienţilor care prezintă cele două patologii şi, de asemenea, caracteristicile generale ale acestora. La prima vedere, majoritatea pacienţilor erau supraponderali sau obezi; acest fapt ne-a dus cu gândul că asocierea celor două patologii ar putea fi cauzată chiar de elementul fiziopatologic care declanşează DZ2, element caracteristic obezităţii, şi anume insulinorezistenţa $[1,2]$. Rolul obezităţii şi implicaţiile rezistenţei la insulină în apariţia DZ2 au fost demonstrate fără urmă de echivoc de-a lungul timpului $[3,4]$. Plecând de la constatarea ad-hoc a acestei particularităţi a pacienţilor care prezentau în clinica noastră atât DZ2, cât şi $\mathrm{TH}$, ne-am propus să aprofundăm studiul asupra insulinorezistenţei şi a implicaţiilor ei în această asociere şi să aflăm dacă rezistenţa la insulină reprezintă cauza principală a observaţiilor nostre din clinică.

\section{MATERIALE ŞI METODĂ}

Am analizat, într-un studiu observațional retrospectiv, iniţial un lot de 5.064 pacienți din cadrul clinicii Sanamed Hospital din București, pacienți cu diabet zaharat tip 2, care s-au prezentat la clinică în perioada ianuarie 2016-decembrie 2018. După ce am analizat lotul mare pentru a demonstra ipoteza iniţială a studiului, am dorit să aprofundăm analiza și am creat trei subgrupuri: 50 de pacienți doar cu DZ2, 50 de pacienți doar cu TH și 50 de pacienţi cu DZ2 și TH. Astfel, s-au format lotul 1, lotul 2 și lotul 3.Criteriile de includere în studiu au fost prezența DZ2 la pacienții din lotul 1 și a TH la pacienții din lotul 2. În ceea ce privește lotul 3, criteriul de includere a fost prezenţa concomitentă a DZ2 şi TH. Criterii de excludere din studiu au fost diabetul zaharat de tip 1 pentru lotul 1 și 3, prezența markerilor de autoimunitate tiroidiană specifici tiroiditei cronice limfocitare la lotul 1 şi prezența valorilor crescute ale glicemiei și hemoglobinei glicozilate (HbA1c) la pacienții din lotul 2.

Am urmărit parametrii demografici ai pacienților din cele 3 loturi, caracteristicile clinice și biologice ale acestora. Privind demografia, am analizat sexul, vârsta, proveniența din mediul urban sau rural, statutul de fumător și cel de consumator cronic de etanol. Parametrii biologici analizați pentru toate cele 3 subgrupuri au fost: glicemia, HbA1c, anticorpii antitireoperoxidază (ATPO), hormon de stimulare tiroidiană (TSH), tiroxina liberă (free T4), profilul lipidic (colesterol, trigiceride, HDL, LDL), funcția renală exprimată prin valoarea calculată a ratei de filtrare glomerulare prin metoda MDRD şi creatinina serică, acidul uric și profilul hepatic compus din aspartaminotransferaza (TGO) și alaninaminotransferaza (TGP). Pentru analizele de laborator, s-a folosit sânge venos, determinările specifice fiind făcute prin metoda HPLC (HLG723GB) și metoda spectometriei (Lab 600), sau s-a folosit ser, iar metoda folosită a fost MiniVidas.

Am analizat parametri biologici ai fiecărui participant la studiul din cadrul celor 3 subgrupuri: greutatea exprimată în kilograme și măsurată cu ajutorul unui cântar calibrat și certificat, înălțimea exprimată în metri, indicele de masă corporală (IMC) folosind formula de calcul IMC = greutatea/ înălțimea la pătrat, circumferința abdominală, exprimată în centimetri, măsurată cu taliometrul, tensiunea arterială sistolică și diastolică, exprimate în milimetri coloană de mercur $(\mathrm{mmHg})$, și măsurate cu un tensiometru calibrat și certificat. 
Am mai urmărit și prezența sau absența unor patologii asociate pentru a putea identifica posibilele corelații clince care să ne susțină atât ipoteza inițială a studiului, cât și ipotezele secundare. S-a urmărit prezența sau absența următoarelor comorbidități: hipertensiunea arterială, obezitate, dislipidemie, sindrom metabolic, steatoză hepatică, boală cardiacă ischemică, hipotiroidie, eutiroidie, hipertiroidie, guşă, nodul tiroidian, complicaţii macrovasculare și microvasculare ale diabetului zaharat de tip 2, polineuropatia diabetică periferică, retinopatia diabetică, boala cronică de rinichi, boala arterială periferică, accidentul vascular, infarctul de miocard, insuficența cardiacă congestivă, hiperuricemia, cataracta, glaucomul, insuficența venoasă cronică, depresia și ateromatoza sistemică. Aceste date au fost culese din dosarul pacientului din istoricul patologic personal al fiecărui pacient.

Cercetarea noastră a obţinut avizul nr. 2591 din 12.03.2018 al comisiei de etică a Sanamed Hospital pentru a desfăşura acest studiu observaţional retrospectiv. Fiind un studiu nonintervențional, nu a necesitat formular de consimțământ informat.

Datele folosite au fost introduse în baze de date specifice folosind Microsoft Office Excel 2010; ulterior, analiza statistică a fost realizată cu programul SPSS (Statistical Package for the Social Sciences), versiunea 21, precum şi cu Jamovi, un soft recent realizat și facil întrucât folosește sintaxe elaborate în limbajul de programare R. Statisticile descriptive au oferit o reprezentare vizuală a datelor culese. Astfel, cu ajutorul datelor descriptive, valorile obținute au putut fi evaluate în funcție de forma distribuției (mesocurtică, leptocurtică), asimetrie și boltire. Totodată, un punct major oferit de analizele descriptive a constat în identificarea valorilor extreme care puteau influența rezultatele obținute.

\section{REZULTATE}

Pacienții din cele trei loturi ale studiului nostru au fost albi-caucazieni, români. Ponderea femeilor a fost mai mare $122(81,3 \%)$ și doar $28(18,7 \%)$ bărbați; în lotul cu DZ2, 26 (52\%) au fost femei și $24(48 \%)$ au fost bărbați; pentru lotul cu TH, 48 (96\%) au fost femei și 2 (4\%) au fost bărbați; iar pentru lotul cu DZ2 și TH 48 (96\%) au fost femei şi 2 (4\%) au fost bărbaţi [5].

Ipoteza iniţială a studiului nostru, faptul că există o asociere între DZ2 şi TH, s-a confirmat printr-o diferență puternic semnificativă pe care am constatat-o în ceea ce privește incidența TH în populația generală și incidența din rândul pacienților cu diabet zaharat tip 2. Incidența TH în cadrul celor 5.064 de pacienți cu DZ2 găsită de noi a fost de $789,89 / 10^{5}$ pe an, împărțită astfel: $230,80 / 10^{5}$ pe an la bărbați și $1286,83 / 10^{5}$ pe an la femei. La nivel european, în populația generală referitor la incidența $\mathrm{TH}$, raportările au arătat asftel: $259,12 / 10^{5}$ pe an, $85,36 / 10^{5}$ pe an în ceea ce privește bărbaţii şi $419,72 / 10^{5}$ pe an în rândul femeilor [6].

O altă constatare demnă de a fi menționată a fost riscul crescut al pacienților cu DZ2 de a dezvolta $\mathrm{TH}$, de 3 ori mai mare. În cazul femeilor cu DZ2, la acestea s-a arătat un risc de 6 ori mai mare de a dezvolta TH față de bărbații cu DZ2.

În cadrul studiului nostru, am constatat și un efect semnificativ statistic în ceea ce privește reducerea ponderii obezităţii la pacienții cu ambele patologii. În ceea ce privește dislipidemia, am constatat la pacienții din cadrul lotului 3 (cel ce conține pacienți cu ambele patologii) un risc mai mic pentru hiperlipidemie comparativ cu pacienții din lotul 1 (pacienți doar cu DZ2) şi pacienții din lotul 2 (cei doar cu TH).

O altă diferență semnificativ statistică s-a constatat în ceea ce privește hipertensiunea arterială, ponderea ei a scăzut la lotul 3 față de lotul 1; prin comparație, la lotul $2 \mathrm{~s}-\mathrm{a}$ găsit o pondere mai crescută. Aceeași diferenţă semnificativ statistică între lotul 3 și lotul 1 am constatat-o și în ceea ce privește sindromul metabolic, constatându-se o diferență semnificativ mai mare în lotul 3 versus lotul 2 .

Am mai constatat și un efect protector puternic conferit de asocierea celor două patologii în ceea

TABEL 1. Incidența pacienților diagnosticați cu TH înainte şi după dobândirea DZ2 în lotul studiat şi incidența la nivel european [6]

\begin{tabular}{|l|l|l|l|l|l|l|}
\hline & $\begin{array}{l}\text { Total Subiecți } \\
\text { (n= 5.064) }\end{array}$ & $\begin{array}{l}\text { Bărbați } \\
\text { (n= 2.383) }\end{array}$ & $\begin{array}{l}\text { Femei } \\
\text { (n= 2.681) }\end{array}$ & $\begin{array}{l}\text { Incidență totală } \\
\text { pe an 10 }\end{array}$ & $\begin{array}{l}\text { Incidență la bărbați } \\
\text { pe an 10 }\end{array}$ & $\begin{array}{l}\text { Incidență la } \\
\text { femei pe an 105 }\end{array}$ \\
\hline $\begin{array}{l}\text { Cu TH dobândit după } \\
\text { diagnosticul de DZ2 în } \\
\text { prezentul studiu }\end{array}$ & 80 & 11 & 69 & 788,89 & 230,80 & 1286,83 \\
\hline $\begin{array}{l}\text { Incidența TH în } \\
\text { populația generală a } \\
\text { Europei }\end{array}$ & & & & 259,12 & 85,36 & 419,72 \\
\hline
\end{tabular}




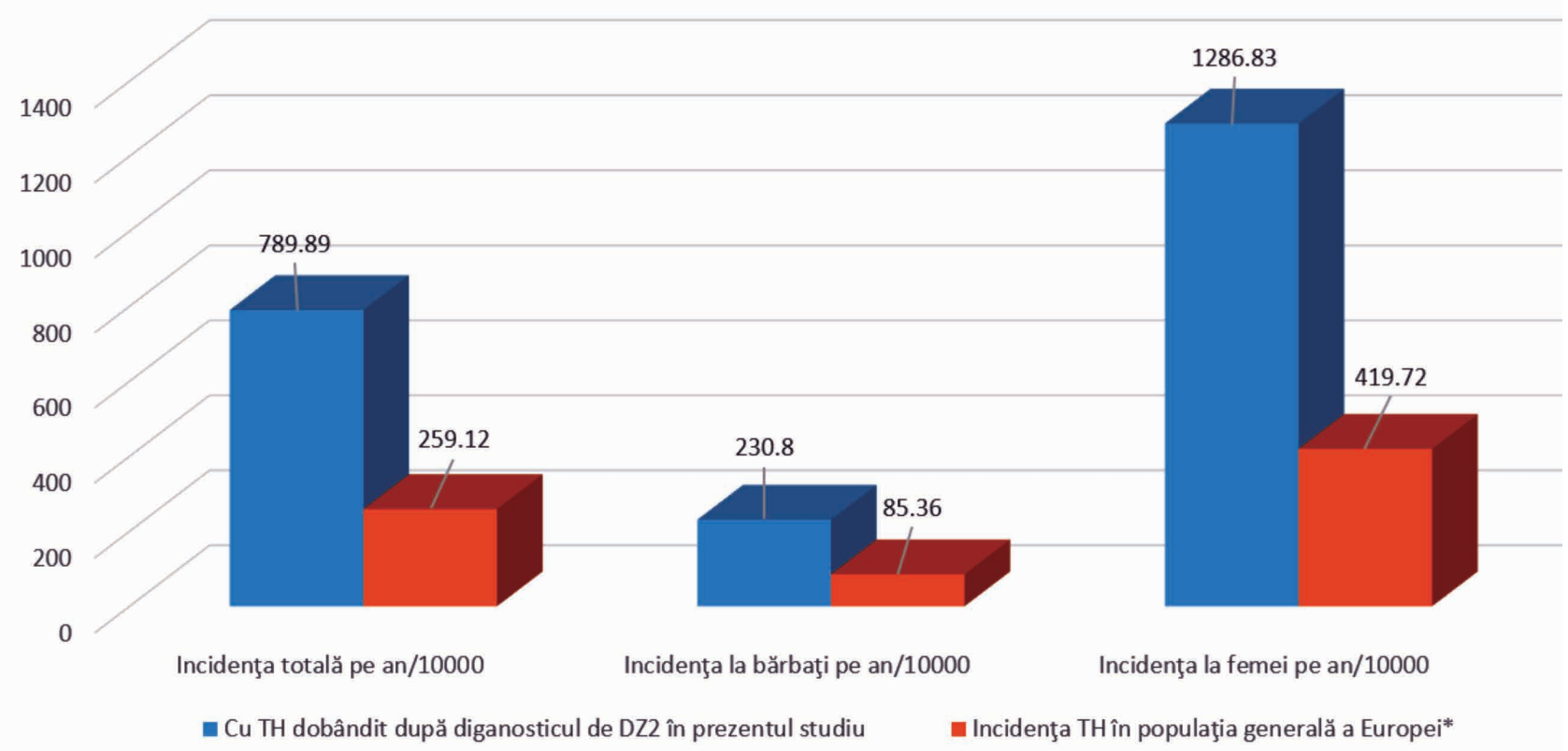

FIGURA 1. Incidența pacienților diagnosticați cu TH înainte şi după dobândirea DZ2 în lotul studiului şi incidența la nivel european

ce privește boala cardiacă ischemică, incidența acesteia fiind de 3 ori mai mică în lotul 3 versus lotul 1. Un alt efect protector, dat de asocierea DZ2 cu TH, s-a constatat în cazul complicațiilor macrovasculare ale DZ2; în cazul complicațiilor microvasculare, s-a constatat aceeași tendință, însă nu a fost semnificativă statistic.

Am evaluat și subgrupuri de pacienți din cele 3 loturi care aveau patologii similare pentru a evalua dacă se corelează semnificativ statistic și ne conduc către posibile cauze ale asocierii dintre DZ2 și TH. Un astfel de subgrup a fost format din pacienți cu polineuropatie diabetică periferică în cadrul lotului 1 și al lotului 3. Am constatat o valoare semnificativ mai mare a glicemiei la pacienții din lotul 3 față de cei din lotul 1 . Tot în ceea ce privește glicemia analizată în unele subgrupuri specifice, am constatat diferențe semnificativ statistice la

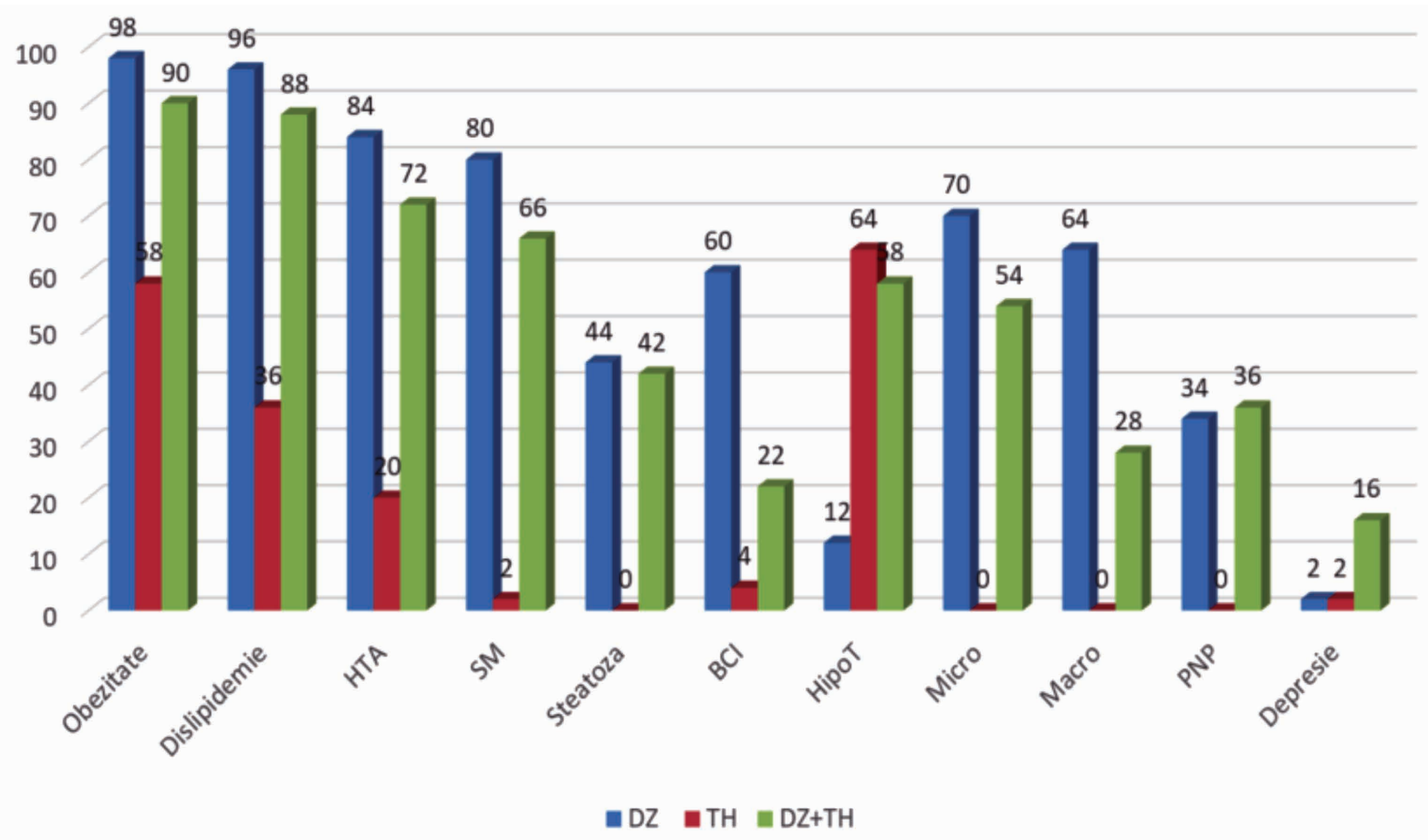

FIGURA 2. Ponderile comorbidităților prezente în cele 3 loturi 
pacienții care mai aveau și hipotiroidie, eutiroidie, dislipidemie, obezitate, boală cardiacă ischemică, complicații macrovasculare și microvasculare (unde este inclusă și polineuropatia diabetică periferică), obezitate şi steatoză hepatică.

Am analizat și pacienții cu sindrom metabolic din lotul 3 și din lotul 1 și am constatat că există o diferență între valorile colesterolului total obținute la acești pacienți. Această constatare ne-a făcut să formulăm ipoteza că cele două patologii pe care le-am studiat produc creşteri ale valorilor colesterolului total atunci când sunt asociate.

Am mai observat un efect protector al asocierii dintre diabetul zaharat de tip 2 și tiroidita autoimună, efect arătat în cazul complicațiilor macrovasculare ale diabetului zaharat. În ceea ce privește complicaţiile microvasculare, s-au observat diferențe, însă acestea nu au avut valoare statistică relevantă. Referitor la complicația microvasculară cel mai des întâlnită la pacienții cu diabet zaharat tip 2, polineuropatia diabetică, nu am găsit diferențe cu semnificație statistică între pacienții din lotul 1 și cei din lotul 3; această constatare a fost în acord cu cea menţionată mai sus referitoare la lipsa semnificației statistice din cazul complicațiilor microvasculare.

Am analizat și o serie de parametri biologici ai pacienților din studiu și am constatat o semnificație statistică legată de nivelul acidului uric, valoarea acestuia fiind mai mare la pacienții din cadrul lotului 1 față de pacienţii din lotul 3 .

În cadrul analizei grupurilor referitor la patologiile asociate, am găsit un grad foarte ridicat de semnificație statistică legat de prevalența depresi-

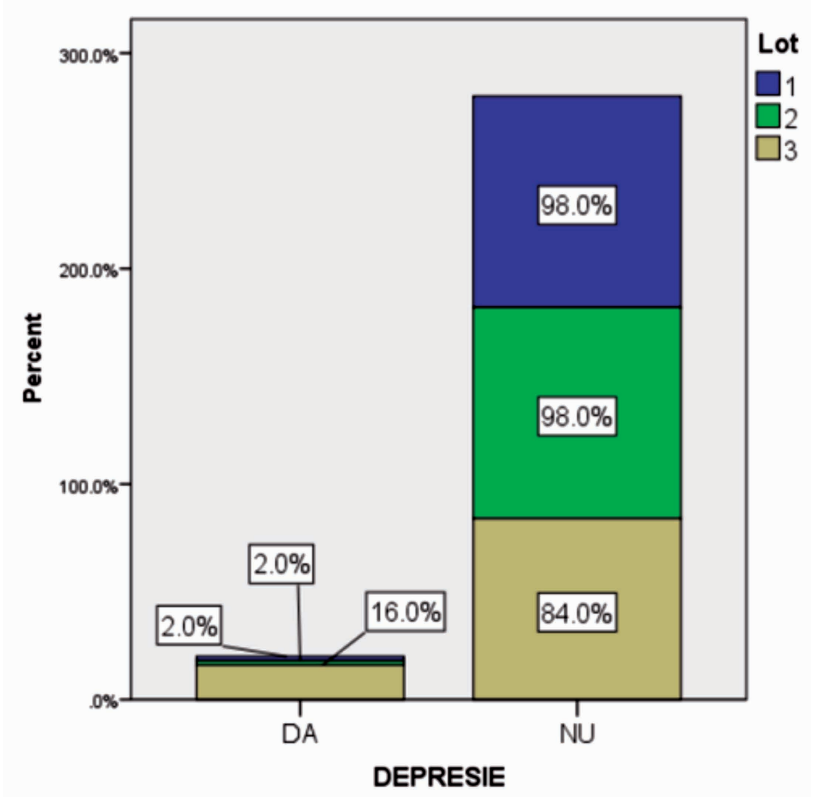

FIGURA 3. Ponderile depresiei în cele 3 loturi ei. Am constatat un risc de 8 ori mai mare de a avea această boală în cazul pacienților care aveau asociere între DZ2 și TH.

\section{DISCUTुII}

O cercetare de acest tip, asupra asocierii dintre DZ2 şi TH, nu a mai fost efectuată până în prezent pe populația din țara noastră. Nici la nivel mondial nu am mai găsit un studiu similar. Faptul că am studiat parametrii demografici, fizici și biochimici - atât în grupurile cu diabet zaharat, cât și în grupurile de control și în subgrupurile ulterior formate pe baza patologiilor asociate - conferă acestui studiu un element de originalitate și este unul dintre principalele atuuri ale studiului. Pentru a elucida însă pe deplin toate aspectele acestei asocieri, mai este nevoie de cercetări ulterioare.

O legătură strânsă a fost descrisă între citokinele proinflamatorii, factorul de necroză tumoralăalfa TNF-alfa, proteina $C$ reactivă, interleukina 2 (IL-2) și interleukina 6 (IL-6) și rezistenţa la insulină. Toate aceste citokine sporesc insulinorezistența [7]. Aceste citokine sunt secretate de către celulele grăsoase din țesutul adipos, care au pe suprafața lor receptori ai TSH. Relaţia directă dintre receptorii hormonului tiroidian (TSH) și insulinorezistență se poate explica prin capacitatea acestora de a crește numărul de adipocite și, astfel, de a crește producţia de citokine proinflamatorii [8]. Aceasta este motivul pentru care, aşa cum am găsit în mai multe studii, atât hipotiroidismul subclinic, cât și hipertiroidismul subclinic sunt patologii cu risc crescut de asociere cu insulinorezistența [9-14].

Legătura dintre valorile TSHşi insulinorezistență la pacienții cu eutiroidie a fost demonstrată deja într-un studiu din 2002 [15]; aceeași constatare am evidențiat-o și în cercetarea noastră.

În studiile țintite la pacienții obezi cu eutiroidie, s-au evidenţiat valori crescute ale TSH [10-17]. Analizând aceași populație de pacienți, în cercetarea noastră am demonstrat, pentru prima dată, o corelație pozitivă între valorile TSH și valoarea numerică a indicelui de masă corporală în rândul pacienților nonobezi cu eutiroidie, cu o valoare maximă a IMC de $29,9 \mathrm{~kg} / \mathrm{m}^{2}$.

În urma analizei statistice a datelor culese în studiul nostru, am constatat o corelație pozitivă a DZ2 cu obezitatea, această corelație fiind mai mare decât în cazul pacienților cu TH, 32\% versus $21 \%$. Intr-un studiu condus de Papazinfropoulou și colab., s-a arătat că valoarea IMC-ului la pacienții cu patologii tiroidiene este mai mare decât cea a pacienților fără aceste patologii [18]. Bazându-ne 
pe descoperirile celor două studii amintite mai sus $[5,18]$, putem afirma că există o corelație cu insulinorezistența la ambele loturi de pacienți, cu DZ2 și cu TH. Mergând mai departe cu acest raționament, putem spune că aceași legătură poate fi valabilă și în cazul pacienților din lotul 3 , care aveau şi DZ2 și TH, această afirmație venind ca o deducție logică a celor enunțate anterior.

Tot în cadrul studiului condus de Papazinfropoulou și colab., s-a mai arătat și o pondere de 12,3\% a patologiilor tiroidiene, de orice fel, la pacienții cu DZ2, prevalența ceea mai ridicată întâlnindu-se la sexul feminin $(p<0,0001)$ [18]. În cercetarea noastră, am evidențiat ponderi asemănătoare: lotul 1 a avut $52 \%$ paciente de sex feminin, lotul 2 a fost compus din 96\% femei, iar lotul 3, cel în care am inclus pacienți cu DZ2 și TH, a fost similar cu lotul 2 , având tot $96 \%$ populație feminină.

Într-un alt studiu, desfășurat în Iordania de Radaideh și colab., s-a constatat o legătură între DZ2 și TH; cercetarea fiind făcută pe pacienți cu DZ2 și urmărind prevalența bolilor tiroidiene și implicațiile autoimune ale acestora la grupul de pacienți țintă. În acest studiu, au arătat că, dintre pacienții cu DZ2, 5,9\% au avut anterior o patologie tiroidiană. $\mathrm{O}$ concluzie a studiului lor a fost faptul că, din totalul de pacienți cu DZ 2, 12,5\% aveau și o boală tiroidiană intercurentă. Au mai demonstrat că există un nivel de autoimunitate, de ATPO crescut în rândul pacienților diabetici de tip 2 de $8,3 \%$ [19].

În cadrul studiului nostru, am evidențiat date asemănătoare privind incidența patologiilor tiroidiene în rândul populației du DZ2, de asemenea, un nivel crescut de ATPO în această populație. Coroborând rezultatele studiului nostru cu cele din studiul lui Radaideh și colab., putem afirma că există o asociere între patologiile țintă studiate (DZ2 și TH).

Tot Radaideh și colab. au mai arătat, la populația cu DZ2 studiată, un grad ridicat de autoimunitate, 29,4\% dintre subiecți având valori pozitive ale ATPO [19].

Studiul nostru a evaluat și prezența sau absența anumitor patologii asociate celor două boli, una dintre acestea fiind dislipidemia. În urma analizei statistice, am constatat faptul că rezultatele obținute de noi au fost comparabile cu rezultatele obținute în alte studii [20]. În studiul condus de Ravishankar și colab., s-a demonstrat că prevalența mai mare a dislipidemiei s-a evidenţiat în grupul de pacienți cu TH (36\%), această valoare fiind mai mare decât cea obținută în grupul cu DZ2 [20]. Analizând valorile profilului lipidic, în această cercetare s-a demonstrat o pondere mai crescută a valorilor numerice pentru toate componentele profilului lipidic (colesterol total, HDL-colesterol, LDL-colesterol și chiar și trigliceride) [20]. Datele analizate în studiul nostru au arătat rezultate similare și ne permit să enunțăm fapul că rezultatele nostre nu au fost doar o întâmplare, ele putând fi luate în considerare ca o posibilă componentă implicată în asocierea DZ2 și a TH.

Studiul nostru, deși unul deschizător de drumuri în acest domeniu, a avut și limitările lui: nu am putut doza HOMA-IR, analiză ce ne-ar fi putut întări concluzia despre legătura pe care cele două patologii studiate $\mathrm{o}$ au prin prisma insulinorezistenței. Rămâne, aşadar, deschisă calea pentru cercetării viitoare mai aprofundate.

\section{CONCLUZII}

Am confirmat ipoteza iniţială a studiului nostru prin faptul că am demonstrat o incidență mai mare a TH în rândul pacienților cu DZ 2 versus incidența TH din rândul populației generale de la nivel european. Diferența dintre incidențe a fost puternic semnificativă, ceea ce a demonstrat ipoteza principală a studiului nostru, și anume că DZ2 și TH se asociază.

Am mai confirmat și ipotezele secundare ale studiului nostru: am evidențiat un rol protector al asocierii dintre DZ2 şi TH referitor la obezitate; am mai arătat și un efect protector al acestei asocieri asupra dislipidemiei; a mai fost demonstrat un rol protector asupra incidenței HTA, prin prisma asocierii celor două patologii tintă ale studiului nostru. Din studiul nostru a reieşit şi rolul protector pe care această asociere, dintre DZ2 şi TH, îl conferă asupra apariţiei steatozei hepatice şi bolii cardiace ischemice, precum și asupra incidenței complicațiilor macrovasculare.

În urma analizei datelor demografice, clinice și paraclinice ale pacienților studiați, am formulat o concluzie importantă a studiului nostru, aceea că un rol extrem de important atât în apariția celor două patologii studiate de noi (DZ2 și TH), cât și în mecanismul de asociere al acestora îl are rezistența la insulină.

Prin cercetarea noastră, am demonstrat că există o asociere certă a DZ2 cu TH, reușind chiar să arătăm și o parte dintre mecanismele clinice și paraclinice implicate în această asociere. Tema rămâne insuficient studiată și va necesita cercetări viitoare pentru a înțelege și aprofunda atât cauzele, cât și implicațiile pe termen scurt, mediu și lung, eventuale metode de prevenție și/sau tratament. 


\section{BIBLIOGRAFIE}

1. Ziegler AG, Schmid S, Huber D, Hummel M, Bonifacio E. Early infant feeding and risk of developing type 1 diabetes-associated autoantibodies. JAMA. 2003 Oct 1;290(13):1721-8.

2. Hagopian WA, Lernmark A, Rewers MJ, Simell OG, She JX, Ziegler AG, Krischer JP, Akolkar B. TEDDY - The Environmental Determinants of Diabetes in the Young: an observational clinical trial. Ann N Y Acad Sci. 2006 Oct;1079:320-6.

3. Tiberti C, Giordano C, Locatelli M, Bosi E, Bottazzo GF, Buzzetti R, Cucinotta D, Galluzzo A, Falorni A, Dotta F. Identification of tyrosine phosphatase 2(256-760) construct as a new, sensitive marker for the detection of islet autoimmunity in type 2 diabetic patients: the non-insulin requiring autoimmune diabetes (NIRAD) study 2 . Diabetes. 2008 May;57(5):1276-83.

4. Brooks-Worrell BM, Boyko EJ, Palmer JP. Impact of islet autoimmunity on the progressive $\beta$-cell functional decline in type 2 diabetes. Diabetes Care. 2014 Dec;37(12):3286-93.

5. Parlițeanu O, Cheța D. Type 2 diabetes and Hashimoto thyroiditis - possible associations and clinical correlations - preliminary results. Romanian Journal of Diabetes Nutrition and Metabolic Diseases 2018;25(3):297-301.

6. Garmendia Madariaga A, Santos Palacios S, Guillén-Grima F, Galofré JC. The incidence and prevalence of thyroid dysfunction in Europe: a meta-analysis. J Clin Endocrinol Metab. 2014 Mar;99(3):923-31.

7. DeFuria J, Belkina AC, Jagannathan-Bogdan M, Snyder-Cappione J, Carr JD, et al. B cells promote inflammation in obesity and type 2 diabetes through regulation of T-cell function and an inflammatory cytokine profile. Proc Natl Acad Sci U S A. 2013 Mar 26; 110(13):5133-8.

8. Heyde E, Morrison JF. Studies on inosine monophosphate dehydrogenase. Isotope exchange at equilibrium. Biochim Biophys Acta. 1976 May 13;429(3):661-71.

9. Kern PA, Ranganathan S, Li C, Wood L, Ranganathan G. Adipose tissue tumor necrosis factor and interleukin-6 expression in human obesity and insulin resistance. Am J Physiol Endocrinol Metab. 2001 May;280(5):E745-51.

10. Muscogiuri G, Sorice GP, Mezza T, Prioletta A, Lassandro AP, Pirronti T, Della Casa S, Pontecorvi A, Giaccari A. High-normal TSH values in obesity: is it insulin resistance or adipose tissue's guilt? Obesity (Silver Spring). 2013 Jan;21(1):101-6.

\section{Conflict of interest: none declared}

Financial support: none declared
11. Maratou E, Hadjidakis DJ, Kollias A, Tsegka K, Peppa M, Alevizaki M, Mitrou $P$, et al. Studies of insulin resistance in patients with clinical and subclinical hypothyroidism. Eur J Endocrinol. 2009 May;160(5):785-90.

12. Dimitriadis G, Mitrou P, Lambadiari V, Boutati E, Maratou E, Panagiotakos DB, Koukkou E, Tzanela M, Thalassinos N, Raptis SA. Insulin action in adipose tissue and muscle in hypothyroidism. J Clin Endocrinol Metab. 2006 Dec;91(12):4930-7.

13. Rochon C, Tauveron I, Dejax C, Benoit P, Capitan P, Fabricio A, et al. Response of glucose disposal to hyperinsulinaemia in human hypothyroidism and hyperthyroidism. Clin Sci (Lond). 2003 Jan;104(1):7-15.

14. Cettour-Rose P, Theander-Carrillo C, Asensio C, Klein M, Visser TJ, Burger AG, Meier CA, Rohner-Jeanrenaud F. Hypothyroidism in rats decreases peripheral glucose utilisation, a defect partially corrected by central leptin infusion. Diabetologia. 2005 Apr;48(4):624-33.

15. Baskin HJ, Cobin RH, Duick DS, Gharib H, Guttler RB, Kaplan MM, Segal RL; American Association of Clinical Endocrinologists. American Association of Clinical Endocrinologists medical guidelines for clinical practice for the evaluation and treatment of hyperthyroidism and hypothyroidism. Endocr Pract. 2002 Nov-Dec; 8(6):457-69.

16. Toruner F, Altinova AE, Karakoc A, Yetkin I, Ayvaz G, Cakir N, Arslan $M$. Risk factors for cardiovascular disease in patients with subclinical hypothyroidism. Adv Ther. 2008 May;25(5):430-7.

17. Lawson E. Correlation between Diabetes Mellitus and Thyroid Dysfunction: Genetic Basis and Literature Review. Advances in Bioscience and Clinical Medicine. 2016;4(2):3-10.

18. Papazafiropoulou A, Sotiropoulos A, Kokolaki A, Kardara M, Stamataki P, Pappas S. Prevalence of thyroid dysfunction among greek type 2 diabetic patients attending an outpatient clinic. J Clin Med Res. 2010 Mar 20;2(2):75-8.

19. Radaideh AR, Nusier MK, Amari FL, Bateiha AE, El-Khateeb MS, Naser AS, Ajlouni KM. Thyroid dysfunction in patients with type 2 diabetes mellitus in Jordan. Saudi Med J. 2004 Aug;25(8):1046-50. PMID: 15322596.

20. Ravishankar SN, Champakamalini, Venkatesh, Mohsin. A prospective study of thyroid dysfunction in patients with type 2 diabetes in general population. iMedPub Journals. 2013;5(1:2). 